УДК 667.637.4:666.3.135

Л.І. КОРЕЦЬ

Любешівський технічний коледж Луцького національного технічного університету

\title{
ДОСЛІДЖЕННЯ ФУНКЦІОНАЛЬНИХ ВЛАСТИВОСТЕЙ ВАРЕНИХ КОВБАС 3 ДОДАВАННЯМ ПШЕНИЧНОЇ КЛІТКОВИНИ 3 ПЕКТИНОМ ГАРБУЗА
}

\author{
Л.И.КОРЕЦ \\ Любешовский технический колледж \\ Луичкого национального технического университета
}

\begin{abstract}
ИССЛЕДОВАНИЕ ФУНКЦИОНАЛЬНЫХ СВОЙСТВ ВАРЕНОЙ КОЛБАСЫ С ДОБАВЛЕНИЕМ ПШЕНИЧНЫХ КЛЕТЧАТКИ С ПЕКТИНОМ ТЫКВЫ
\end{abstract}

L.KORETS

Lyubashovsky Technical College

Lutsk National Technical University

\section{INVESTIGATION OF FUNCTIONAL PROPERTIES OF VARNISH SAUSAGE WITH ADDITION OF WHEAT CLOTH WITH PECTIN PUMPKIN}

\section{https://doi.org/10.36910/6775-2310-5283-2019-12-02}

Мета. Визначення фізико-хімічних показників пшеничної клітковини з пектином гарбуза та функціональних властивостей фаршевих систем; надання техніко-економічної очінки якості результатам дослідження варених ковбас з додаванням пшеничної клітковини з пектином гарбуза.

Методика. При дослідженнях функиіональних властивостей варених ковбас 3 додаванням різної кількості пшеничної клітковини з пектином гарбуза та при гідромодулі добавки від $3 \%$ до 7\%, використовували загальноприйняті методи дослідження: визначення пластичності фаршу проводили методом пресування, напруження зсуву - за допомогою пенетрометру Ulab3-31M.

Результати. Шляхом мікроструктурного аналізу встановлено, щзо пшенична клітковина з пектином гарбуза за розмірами частинок $і$ особливостями ї будови не відрізняється від аналогічних структурних елементів ковбасних фаршів, щуо свідчить про спорідненість білків пшеничних $i$ пектину гарбуза з тваринними білками; досліджено функціонально-технологічні, структурно-механічні, органолептичні показники модельних фаршевих систем та готових ковбасних виробів. Встановлено, щчо рівень заміни м'ясної сировини (свинини напівжирної) в кількості 3\%, 5\%, $7 \%$ пшеничною клітковиною, збагаченою пектином гарбуза, не впливає негативно на иі показники; заміна 5 \% м'ясної сировини в ковбасних виробах з додаванням пшеничної клітковини з пектином гарбуза, дає можсливість отримати розрахунковий економічних ефект 1310,20 грн на $1 \mathrm{~m}$ готової продукції $і$ збільшити рентабельність підприємства на 8,1\% (за иџінами 2018 р.). 
Наукова новизна. Вперше запропоновано удосконалення технологічного процесу виготовлення варених ковбасних виробів методом використання нетрадииійної сировини пшеничної клітковини з пектином гарбуза (ПКЗПГ); досліджено фізико-хімічні показники сировини та готового продукту; доведено, щуо використання ПКЗПГ підвищує вологоутримувальну та жироутримувальну здатність фаршу. Визначено ефективність використання добавки, щзо дає змогу знизити собівартість ковбас $i$ підвищити рентабельність виробництва.

Практична значимість. Результати проведених досліджень поглиблюють сучасні уявлення про джерела сировини рослинного походження, які можна використовувати як харчові добавки в якості замінників м'ясної сировини.

Ключові слова: пектин, клітковина, дослідження, функціональні властивості, пластичність, граничне напруження зсуву, ковбаса.

\section{Постановка проблеми у загальному вигляді і її зв'язок 3 важливими} науковими та практичними завданнями. Сучасний стан харчування населення України характеризується дефіцитом багатьох незамінних факторів в раціоні харчування. У більшості населення спостерігається дефіцит пектинів, повноцінних білків, поліненасичених жирних кислот, вітамінів, мінеральних речовин, харчових волокон та ін. Перспективним напрямком в забезпеченні повноцінного харчування $\epsilon$ створення полікомпонентних продуктів на основі комбінування сировини рослинного та тваринного походження з урахуванням адекватних потреб людини, згідно з сучасними вимогами нутриціології. Особливе місце серед таких біологічно активних добавок, належить клітковині пшеничній 3 пектином гарбуза. Основні властивості пектину гарбуза: розчинність, в'язкість, желеутворююча, гелеутворююча, комплексоутворююча здатність, взаємодія 3 кислотами, ферментами та ін. Комплексоутворююча здатність пектинів гарбуза, грунтується на взаємодії молекул пектину з іонами важких і радіоактивних металів. Клітковина 3 пектином гарбуза має сорбційно-токсичні властивості, їхні волокна активно виводять 3 організму шлаки, токсини, радіонукліди, продукти розпаду білків, жирів, гормонів, холестерин, тому є унікальним продуктом, що зберігає свої властивості і після обробки.

Ковбасні вироби мають велике значення у харчуванні населення, а їх виробництво $\epsilon$ найбільш поширеним методом переробки м'яса та інших продуктів забою тварин у м'ясній промисловості. Важливе значення набуває створення виробів нового покоління, які мають загальнозміцнюючу та профілактичну дію. Ковбасні вироби поєднують у своєму складі рослинну та тваринну сировину. Таке поєднання дає можливість не лише здешевити готовий виріб, але й виготовити високоякісний та повноцінний за хімічним складом продукт, який буде не лише смачним, а й корисним. Систематичне вживання 
варених ковбас, збагачених клітковиною та пектином гарбуза, сприяє виведенню з організму людини токсичних елементів та радіонуклідів $[1,3]$.

Аналіз останніх досліджень, у яких започатковано вирішення проблеми. Треба відмітити, що виробництво продуктів переробки м'яса в Україні характеризується погіршенням сировинного забезпечення i зниженням показників якості м'ясної сировини, що значно ускладнює роботу м'ясопереробних підприємств. У зв'язку з цим необхідно розробляти такий асортимент продуктів, який дозволить використовувати м'ясо різних категорій. Перспективним напрямком розвитку м'ясопереробної промисловості $€$ виробництво комбінованих продуктів харчування 3 використанням рослинних добавок, які здатні регулювати харчову і біологічну цінність, смакові властивості і стабільність структури в процесі зберігання, внести певний вклад в профілактику найбільш поширених захворювань, таких як ожиріння, патологія серцево-судинної системи, алергія [1-4]. Важливого значення набуває створення виробів нового покоління, які мають загальнозміцнюючі, оздоровчі та профілактичні дії.

Результати численних досліджень доводять, що пшенична клітковина 3 пектином гарбуза позитивно впливають на обмін речовин в організмі людини, зменшують накопичення в організмі радіонуклідів, солей важких металів [1, 2, $3,4]$. Тому вивчення властивостей варених ковбасних виробів 3 додаванням пшеничної клітковини, збагаченої пектином гарбуза, розробка технологій $\epsilon$ актуальною і необхідною проблемою для харчової промисловості, і надасть цим виробам лікувально-профілактичні властивості.

Створення нових різновидів варених ковбас придатних для оздоровлення населення, збільшує попит на пектин, як харчової добавки. Тому, насамперед, існує потреба впровадження інноваційних технологій виробництва варених ковбас 3 використання клітковини 3 пектином гарбуза, що дозволило б відмовитися від імпорту чистого пектину, зменшило б витрати на його виробництво і придбання.

Цілі статті. Дослідження фізико-хімічних та функціональних властивостей варених ковбас 3 використанням пшеничної клітковини 3 пектином гарбуза.

Об’єкт дослідження. Технологія варена ковбаса 3 додаванням рослинної добавки, пшеничної клітковини з пектином гарбуза.

Методи дослідження - органолептичні, фізико-хімічні, структурномеханічні, а також методи математичної обробки дослідних даних із застосуванням прикладного програмного забезпечення. 
Виклад основного матеріалу дослідження 3 повним обгрунтуванням отриманих наукових результатів. Основні вимоги до функціональних властивостей фаршу варених ковбасних виробів є: забезпечення зв'язаного стану вологи і жиру, як під час технологічного оброблення, так і в готовому виробі; забезпечення однорідної структури, соковитості та необхідних органолептичних показників готового продукту. Особливістю приготування даного виду ковбас $є$ повне руйнування первинної структури тканин м'яса та формування нової вторинної структури.

Структура варених ковбас формується за рахунок зв'язування води білками м'яса, гелеутворення та утворення водно-білково-жирової емульсії. Основні вимоги для фаршу даної групи ковбас - міцне зв'язування води та жиру після термообробки, що забезпечує потрібний вихід, структуру і високі органолептичні показники. Результати досліджень порівняльної характеристики хімічного складу рослинної та тваринної сировини наведені в таблиці 1.

Таблиця 1

Порівняльна характеристика хімічного складу рослинної і тваринної сировини

$$
(\mathrm{M} \pm \mathrm{m}, \mathrm{n}=5)
$$

\begin{tabular}{|l|c|c|c|}
\hline \multicolumn{1}{|c|}{ Показники, \% } & $\begin{array}{c}\text { Яловичина } \\
\text { І гатунку }\end{array}$ & Свинина напівжирна & ПКЗПГ \\
\hline Волога & $67,29 \pm 1,14$ & $51,01 \pm 2,78$ & $13,40 \pm 0,57$ \\
\hline Сухі речовини & $32,71 \pm 1,14$ & $48,99 \pm 2,78$ & $86,67 \pm 0,54$ \\
\hline Білки & $18,90 \pm 0,61$ & $15,89 \pm 0,17$ & 11,90 \\
\hline Жири & $12,41 \pm 0,90$ & $32,00 \pm 1,20$ & 2,20 \\
\hline $\begin{array}{l}\text { Загальні вуглеводи, в тому } \\
\text { числі клітковина }\end{array}$ & $0,42 \pm 1,16$ & $0,31 \pm 3,31$ & 75,80 \\
\hline Мінеральні речовини & $0,97 \pm 0,04$ & $0,79 \pm 0,01$ & 5,93 \\
\hline
\end{tabular}

Результати досліджень свідчать про те, що ПКЗПГ містить велику кількість сухих речовин $(88,67 \%)$, в основному, за рахунок білків $(11,90 \%)$, вуглеводів $(75,80 \%)$, що характерно для сировини рослинного походження (ПКЗПГ). За вмістом білка ПКЗПГ наближається до м'ясної сировини, перевищуючи свинину напівжирну на 3,99 \% і менше від яловичини I гатунку на 7,0 \%. Вміст жиру в ПКЗПГ на 10,21 \% нижчий, ніж в яловичині I гатунку i на $29,8 \%$ - в свинині напівжирній. За вмістом мінеральних речовин ПКЗПГ перевищує яловичину і свинину відповідно на 4,96 \% і 5,14 \%.

Функціонально-технологічні властивості пшеничної клітковини 3 пектином гарбуза подані в таблиці 2. 
Таблиця 2

Функціонально-технологічні властивості пшеничної клітковини з пектином гарбуза

\begin{tabular}{|l|c|c|c|}
\hline \multirow{2}{*}{\multicolumn{1}{|c|}{ Показники }} & \multicolumn{3}{|c|}{ Пшенична клітковина з пектином гарбуза } \\
\cline { 2 - 4 } & зразок 1 (3 \%) & зразок 2 (5 \%) & зразок 3 (7 \%) \\
\hline Вміст вологи \% & $53,7 \pm 0,3$ & $55,6 \pm 0,3$ & $57,7 \pm 0,3$ \\
\hline Вологоутримувальна здатність,\% & $46,6 \pm 0,6$ & $47,4 \pm 0,6$ & $49,4 \pm 0,6$ \\
\hline Вологозв'язувальна здатність,\% & $19,6 \pm 0,3$ & $21,5 \pm 0,2$ & $24,7 \pm 0,4$ \\
\hline Жироутримувальна здатність, \% & \multicolumn{3}{|c|}{$3 \pm 0,2$} \\
\hline рН & $1,3 \pm 0,1$ & $1,5 \pm 0,1$ & $1,6 \pm 0,1$ \\
\hline Пластичність, 10²см/г & $75,5 \pm 1,11$ & $80,3 \pm 1,11$ & $82,5 \pm 1,11$ \\
\hline Емульгуюча здатність \% & $77,30 \pm 1,13$ & $83,00 \pm 1,13$ & $86,35 \pm 1,13$ \\
\hline Стабільність емульсії, \% & \multicolumn{3}{|c|}{0,31} \\
\hline Зола,\% & \multicolumn{3}{|c|}{} \\
\hline
\end{tabular}

Аналізуючи дані таблиці 2, можна зробити висновок, що пшенична клітковина, збагачена пектином гарбуза, має всі необхідні функціональнотехнічні властивості для використання іiі в якості рослинної добавки у виробництві варених ковбасних виробів.

За рахунок використання пшеничної клітковини з пектином гарбуза у технології варених ковбасних виробів було розроблено нову рецептуру, досліджено фізико-хімічні показники сировини та готового ковбасного виробу, визначено ефективність використання цієї добавки. Результати досліджень фізико-хімічних показників фаршу з пшеничною клітковиною збагаченою пектином гарбуза подано в таблиці 3.

Таблиця 3

Фізико-хімічні показники фаршу з пшеничною клітковиною з пектином гарбуза

\begin{tabular}{|l|c|c|c|c|}
\hline \multirow{2}{*}{\multicolumn{1}{|c|}{ Показники }} & \multicolumn{4}{|c|}{ Взірці модельних ковбасних фаршів } \\
\cline { 2 - 5 } & $\begin{array}{c}\text { Контрольни } \\
\text { й зразок }\end{array}$ & $\begin{array}{c}\text { Зразок №1 } \\
\text { (3\% ПКЗПГ) }\end{array}$ & $\begin{array}{c}\text { Зразок №2 } \\
(5 \% \text { ПКЗПГ) }\end{array}$ & $\begin{array}{c}\text { 3разок №3 } \\
\text { (7\% ПКЗПГ) }\end{array}$ \\
\hline Вміст вологи, \% & $31,0 \pm 0,95$ & $34,9 \pm 0,25$ & $30,2 \pm 0,25$ & $29,7 \pm 0,95$ \\
\hline $\begin{array}{l}\text { Вологозв'язувальна } \\
\text { здатність, \% }\end{array}$ & $30,3 \pm 0,6$ & $30,9 \pm 0,25$ & $28,5 \pm 0,6$ & $25,9 \pm 0,6$ \\
\hline Пластичність, $10^{3} \mathrm{~cm}^{3} / \Gamma$ & $26,3 \pm 1,2$ & $27,9 \pm 0,95$ & $27,5 \pm 1,2$ & $21,9 \pm 0,95$ \\
\hline $\mathrm{pH}$ & $6,2 \pm 0,2$ & $6,3 \pm 0,2$ & $6,2 \pm 0,2$ & $6,3 \pm 0,2$ \\
\hline
\end{tabular}


За контроль було взято ковбасу варену «Окрему» I гатунку за ДСТУ 4436:2005, до складу рецептури якої входить лише м'ясна сировина (контроль №1). Модельованими компонентами в рецептурі були: яловичина I гатунку, свинина напівжирна, шпик боковий, ПКЗПГ. Залежно від поставленої мети здійснювали заміну свинини напівжирної ПКЗПГ в кількості $3 \%$ (експериментальна ковбаса №1), 5 \% (експериментальна ковбаса №2), 7 \% (експериментальна ковбаса №3).

Виходячи 3 даних таблиці 3, можна зробити висновок, що при додаванні різної кількості пшеничної клітковини 3 пектином гарбуза, консистенція фаршу змінюється, стає більш щільною та утримує більше зв'язаної вологи у своєму складі. Пшенична клітковина має високі показники вологоутримувальної та вологозв'язувальної здатності, що дає їй перевагу використання у харчовій промисловості.

Фізико-хімічні показники готового ковбасного виробу 3 пшеничною клітковиною з пектином гарбуза наведено у таблиці 4.

Таблиця 4

Фізико-хімічні показники готового ковбасного виробу

\begin{tabular}{|c|c|c|c|c|}
\hline Показники & $\begin{array}{c}\text { Контрольний } \\
\text { зразок }\end{array}$ & $\begin{array}{c}\text { Зразок №1 } \\
\text { (3\% П ПКЗГГ) }\end{array}$ & $\begin{array}{c}\text { Зразок №2 } \\
\text { (5\% ПКЗПГ) }\end{array}$ & $\begin{array}{c}\text { Зразок №3 } \\
\text { (7 \% ПКЗПГ) }\end{array}$ \\
\hline Вміст вологи, \% & $46,6 \pm 0,2$ & $47,9 \pm 0,6$ & $48,1 \pm 0,6$ & $48,9 \pm 0,6$ \\
\hline $\begin{array}{l}\text { Вологозв'язувальна } \\
\text { здатність, \% }\end{array}$ & $22,5 \pm 0,5$ & $24,1 \pm 1,5$ & $31,9 \pm 0,5$ & $38,1 \pm 1,5$ \\
\hline $\begin{array}{l}\text { Вологоутримувальна } \\
\text { здатність, \% }\end{array}$ & $53,4 \pm 0,9$ & $71,6 \pm 1,5$ & $79,1 \pm 1,5$ & $81,5 \pm 0,9$ \\
\hline $\begin{array}{l}\text { Жироутримувальна } \\
\text { здатність, \% }\end{array}$ & $71,6 \pm 0,5$ & $76,9 \pm 0,5$ & $51,7 \pm 0,5$ & $67,8 \pm 0,5$ \\
\hline Вміст білку, г & $15,7 \pm 0,2$ & $12,2 \pm 0,6$ & $13,3 \pm 0,6$ & $13,0 \pm 0,6$ \\
\hline Вміст золи, \% & $0,95 \pm 0,2$ & $0,95 \pm 0,2$ & $1,25 \pm 0,1$ & $2,0 \pm 0,1$ \\
\hline Вміст жиру, \% & $16,4 \pm 0,1$ & $14,8 \pm 0,5$ & $15,1 \pm 0,1$ & $19,9 \pm 0,5$ \\
\hline Напруження зсуву, Па & $6927 \pm 1,0$ & $8731 \pm 1,0$ & $5382 \pm 1,0$ & $4666 \pm 1,0$ \\
\hline Пластичність, $10^{3} \mathrm{~cm}^{3} / \Gamma$ & $7,1 \pm 0,1$ & $5,3 \pm 0,1$ & $5,2 \pm 0,1$ & $5,2 \pm 0,1$ \\
\hline $\mathrm{pH}$ & $5,9 \pm 0,1$ & $5,8 \pm 0,1$ & $5,9 \pm 0,1$ & $5,9 \pm 0,1$ \\
\hline
\end{tabular}

За показниками дослідження таблиці 4, можна зробити висновок, що найкращим та найоптимальнішим за співвідношенням елементів хімічного складу є зразок № 3, який має високі показники: золи $-2 \%$, білка -13 \% і 
майже $20 \%$ жиру. Отже, пшенична клітковина з пектином гарбуза підвищує здатність ковбасного виробу зв'язувати воду, за їі унікальною специфікою будови та хімічного складу.

В зв'язку з вищевказаним, були проведені дослідження впливу масової долі рослинної добавки на формування структурно-механічних властивостей варених ковбас (рис. 1).

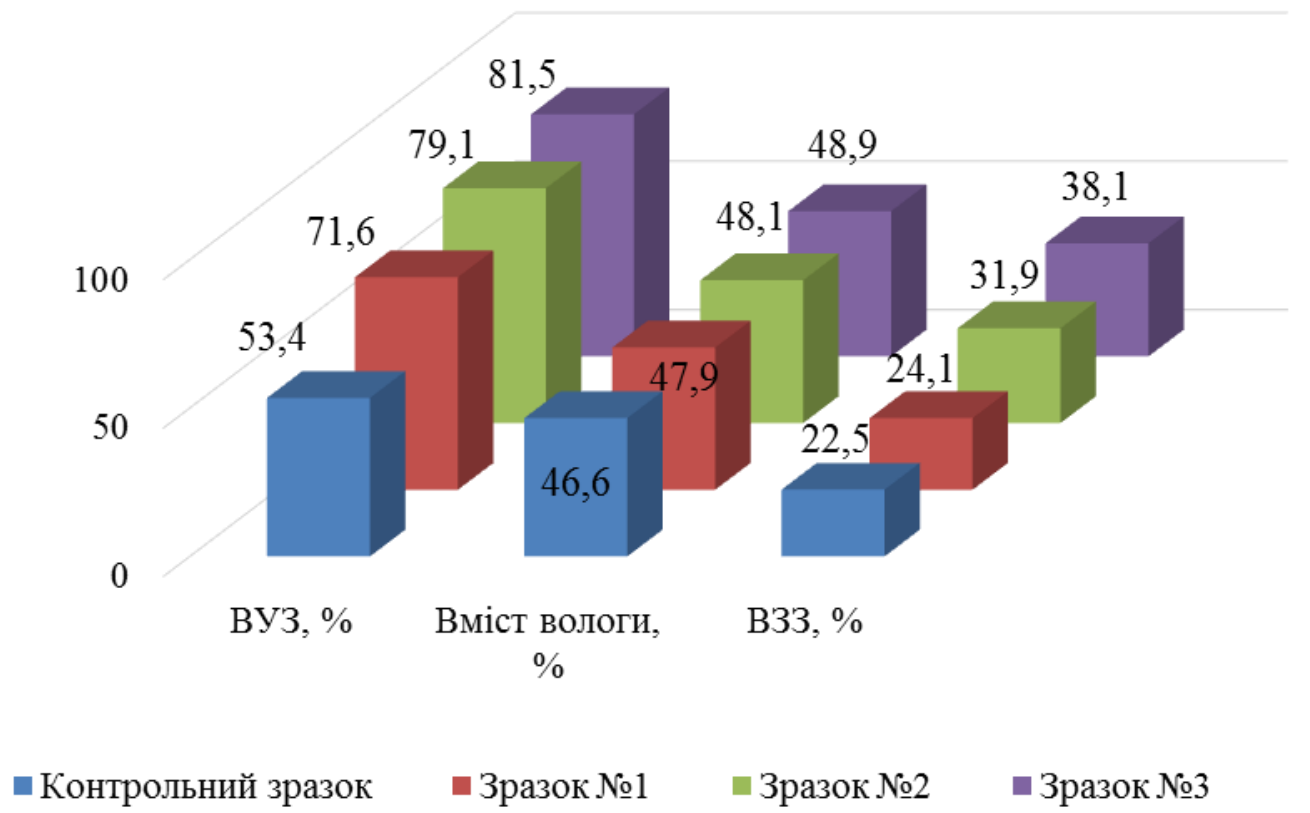

Рис. 1. Характеристика дослідженої вареної ковбаси з пшеничною клітковиною, збагаченою пектином гарбуза

Найбільше граничне напруження зсуву у дослідного зразка № 1 . Рослинна добавка, яку вводили в рецептуру ковбасних виробів, набухає i утворює стійку консистенцію, зв'язує та утримує воду і жир, надає соковитості і смаку готовому виробу. За даними гістограми, досить добре помітно, що чим більший відсоток доданої пшеничної клітковини з пектином гарбуза у складі рецептури, тим вищі показники вологоутримувальної та вологозв'язувальної здатностей.

Результати дослідження фізико-хімічних показників готових ковбасних виробів з додаванням пшеничної клітковини з пектином гарбуза та їх аналіз дав змогу упевнитися, що ми отримали найоптимальніший за співвідношенням елементів в хімічному складі продукт, який має високі показники білка, жиру і золи. Утворилась стійка консистенція, що зв'язує і утримує воду, жир, надає соковитості, смаку готовому виробу; стабільність структури фаршу впливає на зовнішній вигляд готового продукту. 


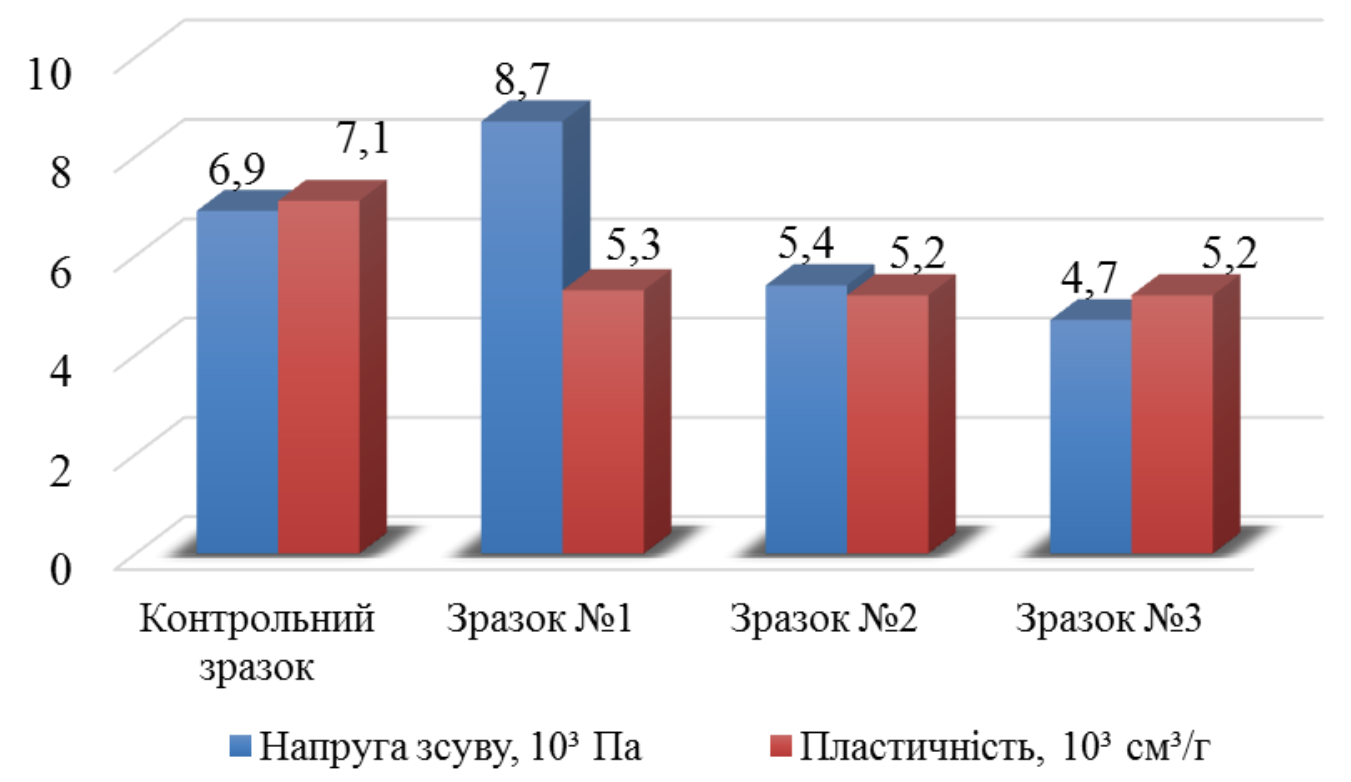

Рис. 2. Зміна граничної напруження зсуву та пластичності у дослідних зразках

Основними вимогами функціональних властивостей готових варених ковбасних виробів $\epsilon$ : забезпечення зв'язаного стану вологи і жиру, як під час технологічного оброблення, так i в готовому виробі; забезпечення однорідності структури, соковитості та необхідних органолептичних показників готового продукта [1-4].

3 додаванням різної кількості пшеничної клітковини з пектином гарбуза консистенція готового виробу змінюється, стає більш щільною і утримує більше зв'язаної вологи у своєму складі (рис. 3).

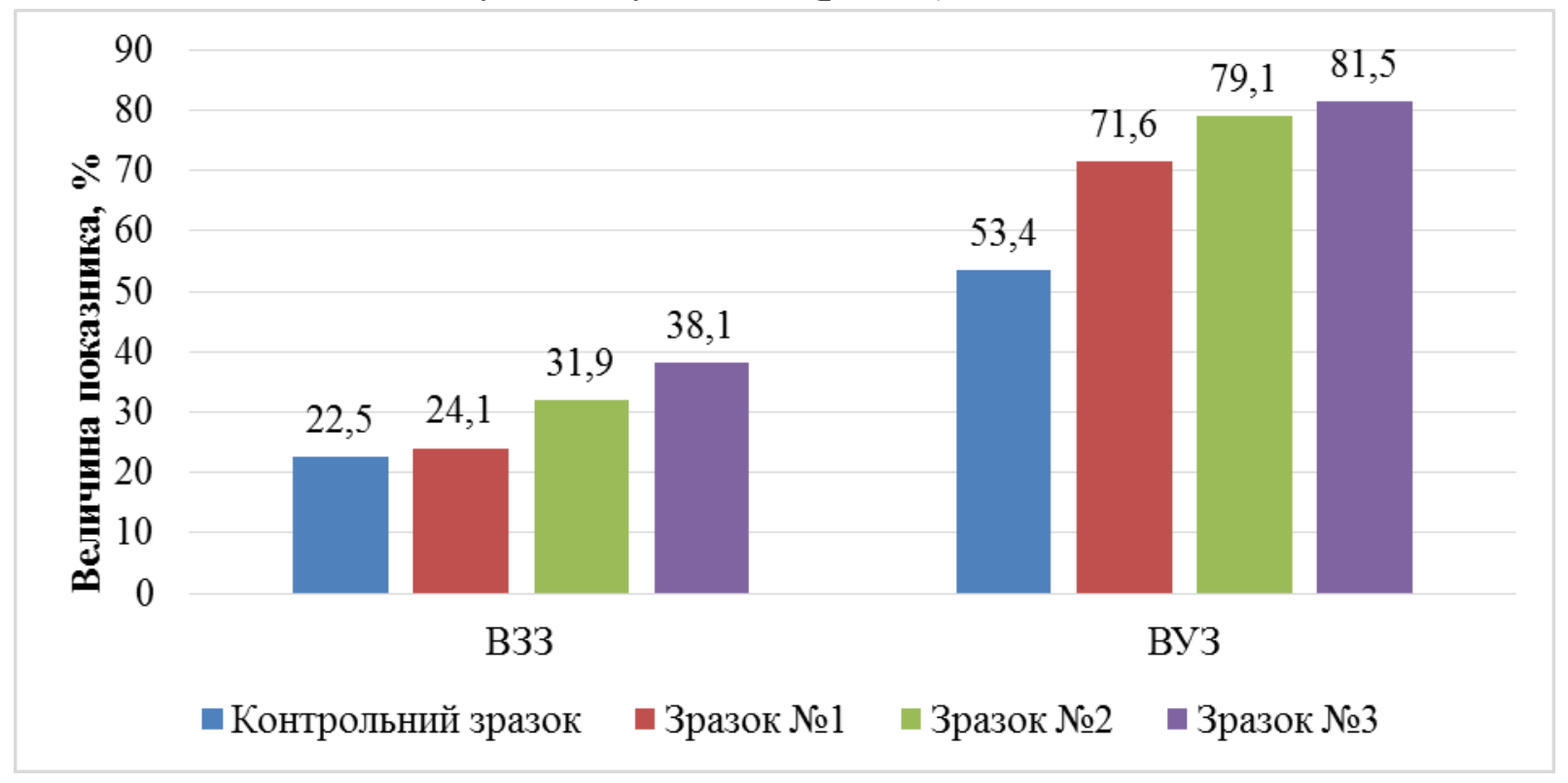

Рис. 3. Характеристика готового ковбасного виробу 
Проаналізувавши дані 3 гістограми, можна сказати, що пшенична клітковина має високі показники вологоутримувальної і вологозв'язувальної здатності, що дає їй перевагу в використанні харчовій промисловості. Доданий рослинний компонент в своєму складі містить (на 100 г продукту): білків - 16,0; жирів - 4,0; вуглеводів - 11,0. Даний компонент не завдає великого впливу на хімічний склад м'ясної сировини, так як у своєму складі містить невелику кількість білків, жирів та вуглеводів.

Соціальний ефект полягає в розширенні асортименту варених ковбасних виробів з рослиною добавкою (ПКЗПГ) та в задоволені попиту населення в продуктах з підвищеною біологічною цінністю. Техніко-економічні показники подано в таблиці 5.

Таблиця 5

Розрахунок основних техніко-економічних показників впровадження результатів дослідження

\begin{tabular}{|c|c|c|c|c|}
\hline \multirow[b]{2}{*}{ Найменування показників } & \multirow{2}{*}{$\begin{array}{c}\text { Одиниця } \\
\text { вимірювань }\end{array}$} & \multicolumn{2}{|c|}{ Показники } & \multirow{2}{*}{$\begin{array}{l}\text { Різниця } \\
\text { «-» «+» }\end{array}$} \\
\hline & & $\begin{array}{c}\text { до } \\
\text { впровадження } \\
\end{array}$ & $\begin{array}{c}\text { після } \\
\text { впровадження } \\
\end{array}$ & \\
\hline Обсяг виробництва & т/добу & 1 & 1 & 0 \\
\hline Ціна за 1т продукції & грн. & 71000 & 71000 & 0 \\
\hline Собівартість продукції на 1т & грн. & 33871,1 & 32560,9 & $-1310,2$ \\
\hline Прибуток & грн./т & 37128,9 & 38439,1 & $+1310,2$ \\
\hline $\begin{array}{l}\text { Витрати на 1грн виробленої } \\
\text { продукції }\end{array}$ & грн. & 0,51 & 0,46 & 0,05 \\
\hline Рентабельність продукції & $\%$ & 69,6 & 78,0 & 8,4 \\
\hline
\end{tabular}

Аналізуючи дані таблиці 5, можна зробити висновок, що заміна певного відсотка м'ясної сировини на рослинну є досить ефективною та економічно вигідною. Таким чином, після додавання в рецептуру вареного ковбасного виробу рослинної добавки прибуток підприємства зросте на 1310,2 грн/т. Ціна продукту залишиться незмінною, а рентабельність виготовлення помітно зросте.

Висновки. Дослідженні фізико-хімічних показників пшеничної клітковини 3 пектином гарбуза у сировині та готовому ковбасному виробі показали, що використання пшеничної клітковини 3 пектином гарбуза обумовлює ряд позитивних властивостей варених ковбас. Використання рослинної добавки дає можливість покращити структуру, збагатити кінцевий продукт вітамінами, мінеральними речовинами і харчовими волокнами, а в 
сукупності, отримати варені ковбасні вироби функціонального призначення, підвищеної якості, харчової та біологічної цінності.

Економічний ефект у грошовому еквіваленті на час проведення досліджень складав понад 1310,20 грн/т, що дозволило збільшити рентабельність нового вареного ковбасного виробу на 8,1\%.

\section{Список використаних джерел}

1. Віннікова Л.Г., Гарбуз В.Г. Підвищення функціонально-технологічних властивостей зернової сировини для використання в м'ясних системах // Зб. наук. пр. Одеса: ОНАХТ, 2004. - Вип. 27. - с. 81-84.

2. $\quad$ Гарбуз В.Г. Структурообразующая добавка для мясных продуктов на основе зерновых культур // Зернові продукти та комбікорми. - 2004. - №3. - С. 19-21.

3. Донченко Л.В. Пектин: осовные свойства, производства и применение / Л.В. Донченко, Г.Г. Фирсов. - М. : ДеЛи принт, 2007. - 276 с.

4. Рогов И.А. Технология мяса и мясных продуктов / И. А. Рогов, А. Г. Забашта, Г.П. Козюлин - М.: Колос, 2009. - 711 с.

Цель. Определить физико-химические показатели пшеничной клетчатки с пектином тыквы и функциональных свойств фаршевых систем; представить техникоэкономическую оченку качества результата исследования вареных колбас с добавлением пшеничной клетчатки с пектином тыквы.

Методика. При исследованиях функииональных свойств вареных колбас $c$ добавлением разного количества пшеничной клетчатки с пектином тыквы и гидромодуля добавки от $3 \%$ до 7 \% использовали общепринятые методы. Определение пластичности фарша проводилось методом прессования, напряжсение смещения - на пенетрометре Ulab3-31M.

Результаты. Путем микроструктурного анализа установлено, что пшеничная клетчатка с пектином тыквы по размерам частии и особенностями ее строения не отличается от аналогичных структурных элементов колбасных фармей, что свидетельствует о родстве белков пшеничных и пектина тыквы с жсивотными белками; исследованы функиионально-технологические, структурно-механические, органолептические показатели модельных фаршевых систем и готовых колбасных изделий и установлено, что уровень замены мясного сырья (свинины полужирной) ПКЗПГ в количестве 3 \%, 5 \%, 7 \% отрицательно не влияет на эти показатели; замена 5 \% мясного сырья в колбасных изделиях с добавлением пшеничной клетчатки с пектином тыквы, дает возможность получить расчетный экономических эффект 1310,20 грн. на $1 \mathrm{~m}$ готовой продукции и увеличить рентабельность предприятия на 8,1\% (по ценам 2018).

Научная новизна. Впервые предложено усовершенствование технологического прочесса изготовления вареных колбасных изделий путем использования нетрадиционного сырья - пшеничной клетчатки с пектином тыквы (ПКЗПГ); была разработана новая рецептура, исследованы физико-химические показатели сырья и готового продукта; доказано, что использование ПКЗПГ повышает влагоудерживаюшую $и$ жироудерживающую способность фарша. Определена эффективность использования добавки, которая позволяет снизить себестоимость колбас и повысить рентабельность.

Практическая значимость. Результаты проведенных исследований углубляют современные представления об источниках сырья растительного происхождения, 
которые можно использовать как пищевые добавки в качестве заменителей мясного сырья.

Ключевые слова: пектин, клетчатка, исследования, функциональные свойства, пластичность, предельное напряжение сдвига, колбаса.

Aim. Determination of the physico-chemical parameters of wheat fiber with pumpkin pectin and functional properties of stuffing systems; give a technical and economic assessment of the quality of the research results of boiled sausages with the addition of wheat fiber with pumpkin pectin.

Method. In studies of the functional properties of boiled sausages with the addition of different amounts of wheat fiber with pumpkin pectin and the hydromodule additives from $3 \%$ to 7\%. The determination of the plasticity of minced meat - by pressing, the bias voltage on the device penetrometers Ulab3-31M.

Results. By means of microstructural analysis, it was established that wheat fiber with pumpkin pectin does not differ in size and features of its structure from similar structural elements of sausage minced meat, which indicates the relationship of wheat protein and pumpkin pectin with animal proteins; functional, technological, structural - mechanical, organoleptic indicators of model stuffing systems and ready-made sausages were investigated and it was established that the level of substitution of raw meat (WFWPP) in the amount of 3\%, 5\%, 7\% does not negatively affect these indicators; Replacing 5\% of raw meat in sausages with the addition of wheat fiber with pumpkin pectin makes it possible to obtain a calculated economic effect of 1310.20 UAH. by 1 ton of finished products and increase the profitability of the enterprise by $8.1 \%$ (at 2018 prices).

Scientific novelty. For the first time, it was proposed to improve the technological process of making boiled sausages by using non-traditional raw materials - wheat fiber with pumpkin pectin (WFWPP); a new recipe was developed, the physicochemical parameters of the raw material and finished product were investigated; practically proved that the use of WFWPP increases the moisture-holding and fat-holding capacity of minced meat. Determined the effectiveness of the use of this additive. That allows you to reduce the cost of sausages and increase profitability.

Practical significance. The results of the research conducted deepen modern ideas about the sources of raw materials of plant origin, which can be used as food additives as substitutes for raw meat.

Keywords: pectin, fiber, research, functional properties, plasticity, ultimate shear stress, sausage.

Стаття рекомендована до друку

д.т.н., доиентом Луиьького НТУ Дударєвим I.МІ.

Стаття поступила в редакиію 28.12.2018 р. 